\title{
Cloning and In Vitro-Transcription of Chymosin Gene in E. coli
}

\author{
S.A. El-Sohaimy ${ }^{1}$ Elsayed. E, Hafez ${ }^{2, *}$ and M.A. El-Saadani ${ }^{3}$ \\ ${ }^{I}$ Food Science and Technology Department, Arid land Research Institute, Alexandria, Egypt \\ ${ }^{2}$ Plant Molecular Pathology Department, Arid land Research Institute, Alexandria, Egypt \\ ${ }^{3}$ Mubarak City for Scientific Research and Technology Applications, Alexandria, Egypt
}

\begin{abstract}
Chymosin, commonly known as rennin, is the main milk-coagulating enzyme available in rennet. RNA was extracted from the abomasum of a suckling calf water buffalo and was subjected to RT-PCR using degenerate primers to amplify $850 \mathrm{bp}$ of the chymosin gene. The sequence was aligned with 19 different mammals' chymosin genes. The sequence revealed that there is a similarity to them ranging from $64 \%$ to $98 \%$. The purified recombinant proteins were obtained from the transformed $E$. coli and yeast. The clotting activity of both of the resulting proteins was examined compared to the commercial peers. It was noticed that the concentration of the purified protein ranged from 15,000 to $40,000 \mathrm{MCU}$. Therefore, the activity of the obtained proteins was the same and it was $105 \%$ when compared to the commercial peer. Having examined the cytotoxicity of the purified proteins, the results revealed no toxicity. We can conclude that the obtained recombinant protein is more active and safe even when expressed in bacteria rather than yeast.
\end{abstract}

Keywords: Chymosin, Milk Clotting, Recombinant E. coli and Recombinant Protein.

\section{INTRODUCTION}

Chymosin, commonly known as rennin, is the main milkcoagulating enzyme available in rennet. The aqueous extract contains a chymosin precursor, prochymosin, which is subsequently converted to active chymosin. Commercial preparations of calf rennet contain two forms of chymosin, A and $\mathrm{B}$, usually in the proportion of about $40 \%$ of $\mathrm{A}$ and $60 \%$ of $\mathrm{B}$. Health aspects of rennet as a food ingredient were reviewed and evaluated at the fifteenth meeting of the Joint FAO/WHO Expert Committee on Food Additives in 1972 $[1,2]$.

Biochemically, chymosin (IUB No. 3.4.4.3) is a protein consisting of a single polypeptide chain of 323 amino acids with intra molecular disulfide linkages. It was shown that the only difference between Chymosins A and B is one amino acid in the polypeptide chain; as the Chymosin A contains an aspartic acid residue at position 286, whereas the Chymosin B contains a glycine residue at the same position [3]. Chymosin is produced intracellular as preprochymosin. As a proteolytic enzyme, chymosin hydrolyses a specific bond in kappa-casein of milk, cleaving it into two peptides, para-kappa-casein and a macropeptide. In milk, kappa-casein acts as a micelle stabilizer. After such activity is destroyed by chymosin, milk coagulation occurs. Chymosin A slightly exceeds chymosin B in proteolytic activity, while Chymosin $\mathrm{B}$ is more stable at low $\mathrm{pH}(<3.5)$ than chymosin A $[3,4]$.

*Address correspondence to this author at the Mubarak City for Scientific Research and Technology Applications, Arid Land Institute, Molecular Plant Pathology Department, New Borg El Arab City, 21934, Alexandria, Egypt; Tel: +2012 9876631; Fax: +203 4593423;

E-mail: elsayed_hafez@yahoo.com
Many microorganisms are known to produce rennet-like proteinases which can replace the calf rennet. Microorganisms like Rhizomucor pusillus, R. miehei, Endothia parasitica, Aspergillus oryzae, and Irpex lactis are used extensively for the production of rennet in manufacturing of cheese [4]. Extensive research conducted so far on rennet substitutes has been reviewed by several authors [5-7]. Different strains of species of Mucor are often used for the production of microbial rennet. Whereas best yields of the milk-clotting protease from Rhizomucor pusillus are obtained from semisolid cultures containing $50 \%$ wheat bran; and R. miehei and Endothia parasitica are well suited for submerged cultivation. Using the former, good yields of milk-clotting protease may be obtained in a medium containing $4 \%$ potato starch, $3 \%$ soybean meal, and $10 \%$ barley. During growth, lipase is secreted together with the protease. Therefore, the lipase activity has to be destroyed by reducing the $\mathrm{pH}$, before the preparation can be used as cheese rennet.

Microbial rennet obtained from various microorganisms, being marketed since the 1970s under the trade names such as Rennilase, Fromase, Marzyme, Hanrilase, etc., have proved to be satisfactory for the production of different kinds of cheese. The molecular and enzymatic properties of chymosins have been subject to extensive studies [6]. Although the proteolytic characteristics of the three commonly used fungal rennets are considerably different from those of calf chymosin, this rennet has been used to produce acceptable cheeses. Recently, Novo Nordisk has managed to express one proteolytic enzyme only from the fungus $R$. miehei in the well-known organism A. oryzae. This host organism is able to produce the single protease that cleaves the casein into a glycol-macro-peptide and para-casein by hydrolyzing only at the phe105-met106 peptide bond between phenyl 
alanine and methionine. This mono-component enzyme product has the trade name Novoren [8]. The only major drawback of the microbial rennet used in the manufacturing of cheese is the development of off flavor and bitter taste in both the non-ripened and ripened cheeses. The rennet obtained from microbial sources is more proteolytic in nature, compared to the rennet obtained from animal sources, resulting in production of some bitter peptides during the process of cheese ripening [9]. Hence, attempts have been made to clone the gene of calf chymosin, and to express it in some selected bacteria, yeasts, and molds.

In recent years, recombinant DNA technology has made it possible to obtain calf chymosin, as a fermentation product, from nontoxicogenic and nonpathogenic strains of bacterium, yeast or filamentous fungus, which were transformed with a plasmid vector containing one of the chymosin precursor's DNA sequence code. Due to the increasing demand on cheese production worldwide, i.e. $4 \%$ per annum over the past 20 years, equal to 13.533 million tons [3], coincided with the reduced supply of calf rennet, it was necessary to search for rennet substitutes, such as microbial rennet. At present, microbial rennet is used for one-third of the cheese production size worldwide.

Due to shortage of calf stomachs and the economic value of cheese rennet, the gene of calf chymosin was one of the first genes of mammalian enzymes that was cloned and expressed in microorganisms [10]. Many different laboratories have cloned the gene of calf prochymosin in Escherichia coli, and analyzed the structure of the gene as well as the properties of the recombinant chymosin [11]. The expressed proenzyme in E. coli is mainly exiting as insoluble inclusion bodies, comprising of reduced prochymosin as well as molecules that are interlinked by disulphide bridges. After disintegration of cells, inclusion bodies are harvested by centrifugation. The individual laboratories have reported some differences in the process of re-naturation of prochymosin from the inclusion bodies, but all have followed the same general scheme. The enzymatic properties of recombinant $E$. coli chymosin are indistinguishable from those of native calf chymosin [12]. The enzymes were identical when observed by immunodiffusion in gels, but a slight difference was observed by enzyme linked immunosorbent assay (ELISA) [13].

\section{MATERIALS AND METHODS}

\section{RNA Extraction}

RNA was extracted from the abomasum of a suckling calf water buffalo and was isolated using RNA extraction kit (QIAgene, Germany). The cDNA was synthesized using c DNA synthesis kit (Pharmacia). The second step PCR was performed using a degenerate sense primer, 5'-TGG CAA AAT GTA CCC ACT GA-3' and an anti-sense primer, 5'ATG TGT GCA TGT GTG TGT GC-3'. PCR amplification carried out in a total volume of $50 \mu \mathrm{l}$ contains $5 \mu \mathrm{l}(5 \mathrm{x}$ Green Go Taq flexi buffer (promega, USA ), $5 \mu \mathrm{l}$ (5 x colorless Go Taq flexi buffer (Promega, USA), (100mM Tris- $\mathrm{HCl}$ (pH 8.8 at $\left.\left.25^{\circ} \mathrm{C}\right) 500 \mathrm{mM} \mathrm{KCl}\right), 5 \mu \mathrm{MgCl} 2(25 \mathrm{Mm})$ (promega, USA), $2 \mu \mathrm{l} 4 \mathrm{dNTPs}$ mixture (10 mM of each) (BIORON, Germany), $4 \mu \mathrm{l}$ RNA of chymosin, $4 \mu \mathrm{l}$ of each primer $(20 \mathrm{pmol} / \mu \mathrm{l}), 2 \mathrm{U}$ Taq polymerase $(5 \mathrm{U} / \mu \mathrm{l})$ (promega, USA), to complete the volume up to $50 \mu \mathrm{l}$ with sterile ddH2O; the reaction mixtures were subjected to amplification as follows: initial denaturation step at $95^{\circ} \mathrm{C}$ for 3 min, followed by 35 cycles of amplification with denaturation at $95^{\circ} \mathrm{C}$ for $1 \mathrm{~min}$, annealing at $55^{\circ} \mathrm{C}$ for $1 \mathrm{~min}$ and extension at $72^{\circ} \mathrm{C}$ for 1 min ending with extension at 72 for 10 min, the thermocycler (PTC-200 Peltier, USA) was used for performing PCR amplification. PCR product was applied on $1 \%$ agaros gel to determine the MW of chymosin gene.

\section{DNA Sequencing and Accession Number}

The PCR product $(850 \mathrm{bp})$ was subjected to DNA sequencing (MACROGEN, Korea). Sequence analysis was done using CLUSTAL W 1.4 program. The nucleotide sequences were analyzed with the BLAST database (http//:www.ncbi.nlm.nih.gov) and the DNA sequence was submitted into the GenBank under accession number FJ56234.

\section{Cloning and Sub-Cloning of Chymosin Gene}

Cloning of amplified PCR products was done by T/A based cloning protocol, using TOPO TA Cloning ${ }^{\circledR}$ (with $\mathrm{pCR}^{\circledR}$ 2.1-TOPO ${ }^{\circledR}$ Cloning vector) and (a TOP 10 E-coli strain) (Invitrogen ${ }^{\mathrm{TM}}$, USA). The chymosin gene was released from the pCR ${ }^{\circledR}$ 2.1-TOPO ${ }^{\circledR}$ vector using EcoRI restriction enzyme. Meanwhile the released fragment was purified by EzWay ${ }^{\mathrm{TM}}$ Gel Extraction kit (KOMBIOTECH. Korea) and was ligated into the lineraized prokaryotic expression pPROEX HT (life technologies, USA). The sub-cloning was done according to the protocols outlined by Life Technologies (Invitrogen). For more acceptable protein for the human, we tried to sub-clone the functional gene into PichiaPink $^{\mathrm{TM}}$ Yeast Expression system (Invitrogen Company) according to the manufacturing procedure.

\section{Chymosin Purification using 6x Histidine Affinity- Tagged Method}

Chymosin purification was carried out by Ni-NTA resin matrix (QIAGEN Inc., USA). The induced bacterial cells were pelleted and resuspended in 4 volumes of lyses buffer (50mM Tris- $\mathrm{HCl}\left(\mathrm{PH} 8.5\right.$ at $\left.4{ }^{\circ} \mathrm{C}\right), 5 \mathrm{mM} 2$-mercaptoethanol, $1 \mathrm{mM}$ PMSF). The suspension was sonicated until $80 \%$ of the cell was lysed. The cell debris was removed by centrifugation; the supernatant was removed to a new tube (crude supernatant). Affinity purification was done according to the protocols outlined by Life Technologies, Invitrogen.

\section{Solubilization and Renaturation of Chymosin Protein}

The procedures developed by Marton [14]; the inclusion pellets were solubilized in $8 \mathrm{M}$ urea buffer $(\mathrm{pH} 8)$. The urea mixture was incubated at $25^{\circ} \mathrm{C}$ for $1 \mathrm{~h}$ before the insoluble molecules were removed by centrifugation. The urea solution was then diluted in a high $\mathrm{pH}$ buffer $(\mathrm{pH}$ 10.7) for renaturation of chymosin. After the insolubilization carried out in $8 \mathrm{M}$ urea, the inclusion body solution was diluted with phosphate buffer $\mathrm{pH} 10.7$; the solution was incubated at $25^{\circ} \mathrm{C}$ for $1 \mathrm{~h}$ and then adjusted to $\mathrm{pH} 8$ and incubation was continued at $25^{\circ} \mathrm{C}$ for $1 \mathrm{~h}$. The solution was transferred and allowed to dialyze against buffer $(20 \mathrm{mM}$ Tris/ $\mathrm{HCl} \mathrm{pH} 8.0$, $50 \mathrm{mM} \mathrm{NaCl}, 1 \mathrm{mM}$ EDTA) at $4{ }^{\circ} \mathrm{C}$ overnight. The folded Streptokinase was then assayed as thrombolytic agent 


\section{Gel Electrophoresis and Western Blots for Recombinant Protein}

Protein samples were prepared according to Wessel and Flugge [1984] and SDS-PAGE was performed according to [15]. $12 \%$ polyacrylamide gel was used for protein separation in the presence of pre-stained molecular weight markers (14 -116.0KD) (Jena Bioscience, Germany). Proteins were transferred to Nitrocellulose membrane (Costa, Bio Blot, Canada) for $1 \mathrm{~h}$ at $0.3 \mathrm{Amp}$, according to Towbin [16] and color developing was performed using BCIP/NBT liquid Substrate System (Sigma, USA).

\section{Determination of Clotting Activity of Recombinant Chymosin and Commercial Chymosin}

A solution of $0.5 \% \mathrm{x}$-casein in $0.01 \mathrm{M}$ phosphate buffer, $\mathrm{pH}$ 6, containing $0.1 \mathrm{M} \mathrm{NaCl}$, was digested with pure recombinant chymosin and commercial chymosin (sigma, USA)). Enzyme solutions (20-50 pg in $100 \sim 1$ ) were incubated from 30 to $120 \mathrm{~min}$ at $30^{\circ} \mathrm{C}$ and the turbidity reading at $550 \mathrm{~nm}$ was recorded [17].

\section{RESULTS}

\section{RT-PCR for Cloning Chymosin Gene}

The amplified products of the RT-PCR were $850 \mathrm{bp}$ (Fig. 1A), the amplicon was cloned into TOPO TA cloning vector and the recombinant clones were digested using the EcoRI restriction enzyme. The released DNA was ligated into the prokaryotic expression vector (pET32a) and in vitrotranscribed recombinant clones (Fig. 1B).

\section{SDS-PAGE and Western Blot}

The purified protein obtained from the recombinant E. coli $\mathrm{K} 12$ was spread on $12 \%$ SDA polyacrylamide gel
(Fig. 1C) and the results revealed that the obtained protein was about $32 \mathrm{kDa}$. The protein was transferred into nylon membrane and was examined with the specific chymosin antiserum; a positive reaction was obtained as shown in Fig. (1D).

\section{Sequence Analysis of Chymosin Gene}

One of the recombinant plasmids was sequenced using the M13 forwards primers and the obtained nucleotide sequence was analyzed using DNA Blast. The data showed that the DNA sequence belongs to chymosin genes. The DNA nucleotide sequence was submitted into GenBank under the accession number FJ562341.

\section{Phylogenetic Construction for DNA Nucleotide Sequence and Deduced Amino Acids}

Phylogenetic was constructed based on the obtained nucleotide sequence as well as the deduced amino acids. The data presented in Figs (2A and $\mathbf{B}$ ) revealed that the obtained DNA sequence was more likely similar to the other chymosine genes presented on GenBank. In addition, the 20 chymosin genes examined were divided into two different main groups, group 1 contains 18 chymosin genes belonging to Bos species, and group 2 contains only two genes belonging to Camelus species. Whereas, the obtained recombinant chymosin was included within the group 1 and it was closely related to Bos primigenius with identity $64 \%$.

\section{Activity of Recombinant Chymosin Compared to Commercial Lamb Chymosin, RLC}

The main absorbance of the samples containing the recombinant chymosin was 0.056 and that of commercial chymosin (Lamb cyhymosin, RLC) was 0.053 at $\mathrm{A}_{550}$. The results showed that the activity of our recombinant
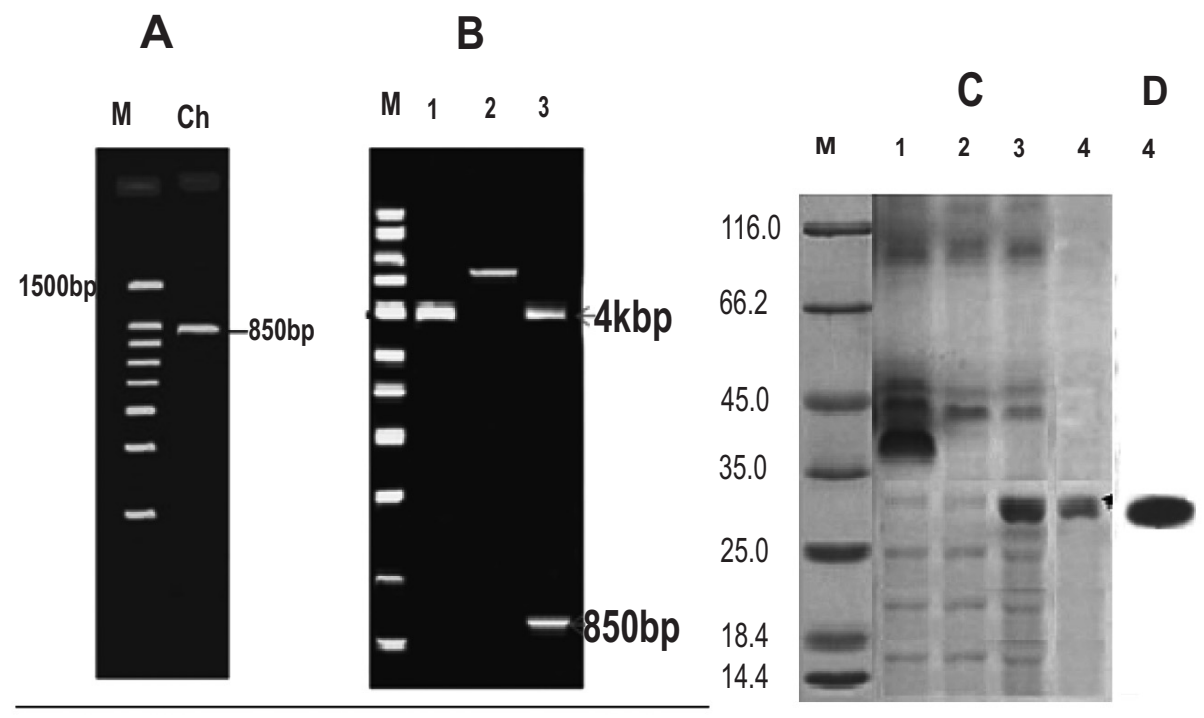

Fig. (1). Amplification, cloning and sub-cloning of the chymosin gene. A: PCR product of chymosin gene using RT- PCR. B: Cloning and DNA release from TOPO TA cloning vector using the EcoRI restriction enzyme. C: the SDS-PAGE for the recombinant clones and its purified protein. D: The western blot for the recombinant chymosin using the specific antiserum. Lanes: M: DNA marker; chymosin PCR product, 1: $\mathrm{pCR}{ }^{\circledR}$ 2.1-TOPO ${ }^{\circledR}$ Cloning vector empty; 2: TOPO containing the amplicon. 3: the released DNA using the EcoRI restriction enzyme. In $\mathrm{C} ; 1,2,3$ are partial purified protein but 4 the purified protein of chymosin gene which is about $32 \mathrm{kDa}$. 


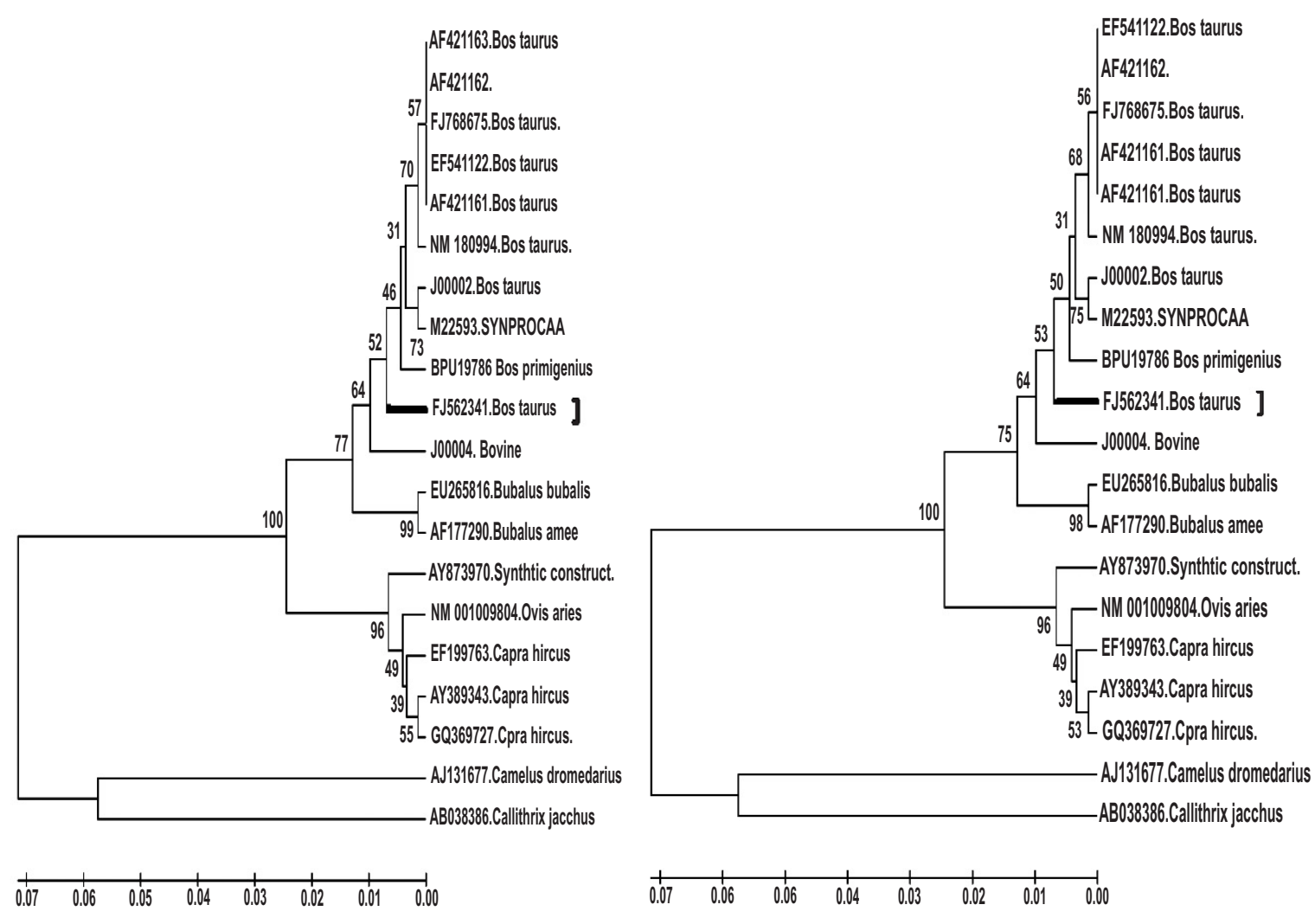

Fig. (2). Phylogenetic tree based on the DNA and deduced amino acids sequences of the obtained chymosin gene compared with the other chymosin genes available at GenBank. The chymosin gene was indicated to with a bold line. The tree was constructed using Mega 4 program.

chamoisn was $105 \%$ compared to $94 \%$ for the commercial chamoisn.

\section{Recovery of Chymosin from Recombinant Yeast}

We managed to transform into the yeast expression system by the obtained chymosin gene. After approximately 96 hours of fermentation, the cells were subjected to protein purification using protein purification kit (Promega, Germany). The formulation may contain from 15,000 to 40,000 MCU (Milk Clotting Units) per $\mathrm{ml}$ of the chymosin enzyme, depending on the market requirements, either in liquid or powder form.

\section{DISCUSSION}

Demain, [18] reported that microbes have been used to produce a myriad of primary and secondary products to benefit mankind for many decades. With the advent of genetic engineering, recombinant proteins entered the market and radically changed the scenario of the pharmaceutical industry. In addition to the use of recombinant DNA, important genes, especially mammalian genes, could be amplified and cloned in foreign organisms. This resulted in a different approach which complicates the biological problem-solving. However, many of biopharmaceuticals are produced using technologically advanced microbial and mammalian cell biosystems. These cell-based protein manufacturing technologies offer many advantages for the production of the pharmaceutically important recombinant proteins which are safe and available in abundant supply [19].

The chymosin gene was isolated from the RNA extracted from a suckling calf water buffalo, and the amplified gene was sequenced and cloned into prokaryotic expression vector. The recombinant clone was transformed into $E$. coli $k 12$ to produce safer chymosin for milk clotting. Vallejo, [20], managed to clone and express the Bos taurus chymosin, and examined it in cheese making industry. The properties of Buffalo chymosin are more stable than those of $B$. taurus chymosin, as they may occupy a significant space in the chymosin market. Mohanty, [21], reported that Bovine chymosin, an aspartyl protease extracted from abomasum of suckling calves, is synthesized in vivo as preprochymosin and secreted as prochymosin which is autocatalytically activated to chymosin.

Both of Vallejo [20] and Maria [22], conducted also subcloning into yeast. They stated that the expression of chymosin in yeast is as useful as an excellent large-scale fermentation tool for the secretion of recombinant foreign proteins. But the chymosin in case [22] was isolated from the milk-fed kid goats. Our gene DNA translation of 153 amino acids differentiated into 3 open reading frames, and showed identity with the other Bos chymosin not exceeding $64 \%$. However, Maria [22] stated that the cDNA contained an open reading frame that predicts a polypeptide of 381 amino acid residues with a signal peptide and a proenzyme region 
which consists of 16 and 42 amino acids respectively. Comparison of the caprine preprochymosin sequence with the corresponding sequences of lamb and calf revealed 99 and 94\% identity at the amino acid level. Mohanty [23], revealed that the gene encoding chymosin was cloned and expressed in suitable bacteria and yeast hosts under the control of lac, trp, trp-beta, gly A genes, and serine hydroxymethyltransferase promoters. Protein engineering of chymosin has also been attempted. A number of companies are now producing recombinant chymosin for commercial use in the manufacturing of cheese.

However, Moir [23-25], stated that a full-length cDNA copy of the mRNA encoding calf chymosin (also known as rennin), a proteolytic enzyme with commercial importance in the manufacturing of cheese, has been cloned in an f1 bacteriophage vector. The nucleotide sequence of the cDNA was determined, and the translation of that sequence into amino acids predicts that the zymogen prochymosin is actually synthesized in vivo as preprochymosin with a 16 amino acid signal peptide.

The recombinant plasmids were transformed into Kluyveromyces lactis and Saccharomyces cerevisiae cells, respectively. Culture supernatants of both yeast transformants showed milk-clotting activity after activation at acid $\mathrm{pH}$. The FLAG-prochymosin fusion was purified from $S$. cerevisiae culture supernatants by affinity chromatography $[22,25]$. Proteolytic activity assayed toward casein fractions indicated that the recombinant caprine chymosin specifically hydrolyzed kappa-casein. The cDNA sequence was cloned into the prokaryotic expression vector pET32a, and the constructed clones were transformed into the $E$. coli $\mathrm{k} 12$ which is safer and did not produce any kind of enterotoxins. The in vitro toxicity test was also carried out and showed no toxicity for the recombinant chymosin. The recombinant bacteria were subjected to invetro-transcription using the IPTG after two hours of inoculation in the proper medium. The activity of the purified protein was $105 \%$ compared to the commercial protein the activity of which was $94 \%$. For more acceptable protein for the human, we tried to sub-clone the functional gene into PichiaPink ${ }^{\mathrm{TM}}$ Yeast Expression system, a much protein amount was obtained but the activity not changed.

Marie and Harold, (1996) [24, 25] reported that the fusion protein was expressed in Escherichia coli and SDSPAGE and the Western blot analysis of chymosin-treated cell lysates showed a $\mathrm{pH}$-dependent cleavage of the fusion proteins. Fusion proteins were also bioselectively immobilized onto biotinylated controlled-pore glass beads and treated with chymosin. CAT was specifically released by chymosin treatment and was identified by SDS-PAGE. About $30 \mathrm{kDa}$ of the purified protein was shown on the SDSPAGE and western blot gave positive reaction with the chymosin antiserum.

Phylogenetic analysis was constructed using 20 of chymosin genes listed on GenBank based on DNA and deduced amino acids. The same phylogeny was obtained both in DNA and amino acids, and the net results revealed that the different chymosin genes share a percent of similarity to each other. The identity percentage between the examined genes ranged from $55 \%$ to $99 \%$. The obtained gene showed similarity with the others chymosin not exceeding $64 \%$. This means that we have a new gene, especially all the reviewers said that their genes are formed of one open reading frame, whereas, ours is consists of three open reading frame combined with promoter region $111 \mathrm{bp}$. The new gene showed good activity compared to the commercial ones. This activity was estimated by $105 \%$ [25].

The least expensive, easiest and quickest expression of proteins can be carried out in E. coli. However, this bacterium cannot express very large proteins. Also, for S-S rich proteins, and proteins that require posttranslational modifications, E. coli is not the system of choice, as it cannot carry out glycosylation and remove the S-S sequences. Sometimes, eukaryotic proteins can be toxic to bacteria. Yeasts that are eukaryotes, have the advantage of growing to high cell densities and are thus suitable for making isotopically-labeled proteins for NMR. The most two utilized yeasts are $S$. cerevisiae and $P$. pastoris. Yeasts can produce high yields of proteins at low cost, proteins larger than $50 \mathrm{kD}$ can be produced, signal sequences can be removed, and glycosylation can be carried out $[19,26]$.

\section{CONCLUSION}

We have a new gene the activity of which is $105 \%$ compared to the commercial one. In addition, the protein purified from bacterial cells $\mathrm{k} 12$ has the same activity of that protein purified from yeast. The gene consists of three open reading frames and has promoter consists of $114 \mathrm{bp}$ length. The in vitro toxicity test also showed no toxicity for the purified chymosin. Further studies are currently conducted on the experimental animals, to study the animal immune response against the purified protein.

\section{REFERENCES}

[1] IDF. World Dairy Situation, Bulletin of the International Dairy Federation. Int Dairy Fed Bull 1990; 247: 24-38.

[2] Stroh WH. Industrial enzymes market. Genetic Eng News 1998; 18: 11 .

[3] Stanley G. Microbiology of Fermented Foods. In: Wood BJB, Eds. Blackie Acad 2 ${ }^{\text {nd }}$ ed. London: 1998; vol. 1: pp. 263-307.

[4] Bhoopathy R. Enzyme technology in food and health industries. Indian Food Ind 1994; 13: 22-31.

[5] Green ML. Review of the progress of dairy science: milk coagulants. J Dairy Res 1977; 44: 159-88.

[6] Fox PF. Exogenous enzymes in dairy technology - a review. J Food Biochem 1993; 17: 173-99.

[7] Farkye NY. Contribution of milk-clotting enzymes and plasmin to cheese ripening. Adv Exp Med Biol 1995; 367: 195-207.

[8] Novoren R. Microbially derived enzymes having enhanced milk clotting activity and method of producing same. Biotimes 1994; 9: $2-4$.

[9] Green ML. Advances in the Microbiology and Biochemistry of Cheese and Fermented Milk. In: Davies FL, Law BA, Eds. England: Applied Science Publication 1984; pp. 1-34.

[10] Nishimori K, Kawaguchi Y, Hidaka M, Beppu T. Expression of cloned calf prochymosin gene sequence in Escherichia coli. Gene 1982; 19: 337-44.

[11] Foltman B. Cheese-Chemistry, Physics and Microbiology General Aspects. In: Fox PF, Eds. $2^{\text {nd }}$ ed. London: Chapman \& Hall 1993; vol. 1: pp. 37-68.

[12] Meisel H, Frister H. Chemical characterization of a caseinophosphopeptide Isolated from in vivo digests of a casein diet. Biol Chem Hoppe Seyler 1988; 369(12): 1275-9.

[13] Kawaguchi Y, Kosugi S, Sasaki K, Uozumi T, Beppu T. Secretion of Mucor rennin, a fungal aspartic protease of Mucor pusillus, by recombinant yeast cells. Agric Biol Chem 1987; 51: 1871-7.

[14] Mellor J, Dobason MJ, Roberts NA, et al. Production and use of microbial enzymes for dairy processing. Gene $1983 ; 24: 1-14$. 
[15] Goff CG, Moi DT, Kohno T, et al. Expression of calf prochymosin in Saccharomyces cerevisiae. Gene 1984; 27: 35-46.

[16] Laemmli UK. Cleavage of structural proteins during the assembly of the head of bacteriophage T4. Nature 1970; 227: 680-5.

[17] Towbin H, Staehelin T, Gordon J. Eds. Electrophoretic transfer of proteins from polyacrylamide gels to nitrocellulose sheets: procedure and some applications. Proc Natl Acad Sci USA 1979; 76: 4350-4.

[18] Douillard R, Ribadeau BD. Termination avee la easino K de l'aetivit protolytique de la pressure, de la pepsin de pore et des Pepsines bovines. Bull Sec Claim Biol 1970; 52: 1429.

[19] Demain, AL, Vaishnav P. Production of recombinant proteins by microbes and higher organisms. Biotechnol Adv 2009; 3: 297-306

[20] Thayer A, Thayer T. Dolly's maker to close its doors. C E News 2003; 86(38): 9 .

[21] Vallejo JA, Ageitos JM, Poza M, Villa TG. Cloning and expression of buffalo active chymosin in Pichia pastoris. J Agric Food Chem 2008; 22: 10606-10.
[22] Mohanty AK, Mukhopadhyay UK, Grover S, Batish VK. Bovine chymosin: Production by rDNA technology and application in cheese manufacture. Biotechnol Adv 1999; 17: 205-17.

[23] Maria CV, Alicia G, Jesús V, Félix C. Molecular cloning and expression in yeast of caprine prochymosin. J Biotechnol 2004; 114: 69-79.

[24] Moir D, Mao J, Schumm JW, Vovis GF, Alford BL, TauntonRigby A. Molecular cloning and characterization of doublestranded cDNA coding for bovine chymosin. Gene 1982; 11: 12738 .

[25] Walsh MK, Harold ES. Investigating the use of the chymosinsensitive sequence of $\kappa$-casein as a cleavable linker site in fusion proteins. J Biotechnol 1996; 3: 235-41.

[26] Mantafounis D, Pitts J. Protein engineering of chymosin; modification of the optimum pH of enzyme catalysis. Protein Eng 1990; 7 : $605-9$.

(C) El-Sohaimy et al.; Licensee Bentham Open.

This is an open access article licensed under the terms of the Creative Commons Attribution Non-Commercial License (http://creativecommons.org/licenses/ by-nc/3.0/) which permits unrestricted, non-commercial use, distribution and reproduction in any medium, provided the work is properly cited. 